\title{
Total gastrectomy with substitution of stomach by jejunal pouch with and without duodenal passage. Study in rats
}

\author{
Tertuliano Aires Neto ${ }^{2}$, Jeancarlo Fernandes Cavalcante², José Brandão-Neto ${ }^{3}$, \\ Irami Araújo Filho ${ }^{3}$, Maria das Graças Almeida ${ }^{3}$,Adriana Augusto de Rezende ${ }^{3}$, \\ Eryvaldo Sócrates Tabosa Egito ${ }^{3}$, Ítalo Medeiros de Azevedo ${ }^{4}$, \\ Laísa Araújo Mohana Pinheiro ${ }^{5}$,Vítor Brasil Medeiros ${ }^{6}$,Aldo da Cunha Medeiros ${ }^{3}$
}

\begin{abstract}
Aires-Neto T, Cavalcante JF, Brandão-Neto J, Almeida MG, Rezende AA, Egito EST, Azevedo IM, Pinheiro LAM, Medeiros VB, Medeiros AC. Total gastrectomy with substitution of stomach by jejunal pouch with and without duodenal passage. Study in rats. Acta Cir Bras [serial on line] Available from: URL: htt://www.scielo.br/acb.

ABSTRACT - Purpose: A comparison was done between the F. Paulino jejunal pouch (FP) and a jejunal pouch (JP) as esophagusduodenum interpositional graft, for replacing the stomach after total gastrectomy. It was investigated the effect of the two procedures on esophagus histology, nutritional state and serum gastrin in rats. Methods: Male Wistar rats weighing $282 \pm 17 \mathrm{~g}$ were randomly submitted to sham operation (S), FP and JP after total gastrectomy. After eight weeks the rats were killed with overdose of anesthetic and tissue was taken from the distal esophagus for histology. Serum levels of total proteins, albumin, iron, transferring, folate, cobalamine, calcium, as well as serum gastrin were determined. Survival was considered. Results: Fourty six rats were operated and thirty survived for eight weeks. Five (33.3\%) died after FP and 11 (52.3\%) after JP ( $p<0.05)$. Postoperative esophagitis occurred in 6 JP rats. At $8^{\text {th }}$ week, no difference was observed on body weight when compared FP and JP rats ( $\left.p>0.05\right)$. The JP rats had a significant decrease in serum albumin, glucose, transferrin, iron, folate and calcium, compared to sham $(\mathrm{p}<0.05)$. Serum gastrin, iron and calcium were significantly higher in JP rats than in FP rats $(\mathrm{p}<0.05)$. In FP rats, transferrin and cobalamine showed significant decrease comparing the preoperative with $8^{\text {th }}$ week levels $(\mathrm{p}<0.05)$. Conclusion: F. Paulino pouch in rats had lower mortality than JP, and esophagitis was not detected in it. JP rats had serum gastrin, iron and calcium unaffected, possibly because of preservation of duodenal passage.
\end{abstract}

KEYWORDS - Total gastrectomy. Jejunal pouch. Nutrition. Gastrin. Reflux.

\section{Introduction}

There are more than 50 described operations for intestinal reconstruction following total gastrectomy ${ }^{1}$. However, the optimal reconstruction of the gastrointestinal tract following total gastrectomy has not been conclusively identified. Patient quality of life will be dependent on the severity of symptoms that develop postoperatively. The optimal reconstruction should be designed to function in a manner akin to the nonoperated gut. The questions that have to be investigated are how to keep nutritional status, determine the benefit of preserving the duodenal food passage as well as the repercussion on the level of gastrinemia, in order to identify which procedures may be advantageous for patients. Clinical trials comparing various methods of intestinal reconstruction following total gastrectomy have been reported ${ }^{2}$. Unfortunately, there has been no uniform operation performed and several different outcome variables have been compared. The search for a superior method of reconstruction has been hampered historically by the reliance on retrospective analyses of small groups of patients ${ }^{1}$. Actually, there is no general agreement with regard to the ideal reconstruction type after total gastrectomy. The importance of the duodenal passage , and the need for pouch reconstruction ${ }^{2}$ have been studied.

The objective of the present study was to examine the benefits and technique of a distal isoperistaltic jejunojejunal stomach replacement pouch (Pernando Paulino pouch) versus interposition of jejunal pouch. Which technique offer the best preconditions related to the importance of the duodenal passage and determine physiologic regulation of postoperative nutrition, mortality, reflux and serum gastrin in rats.

\section{Methods}

Male Wistar rats weighing $282 \pm 17 \mathrm{~g}$ were used for experiments. Rats were housed under controlled conditions of illumination (12/12 hours light/dark cycle), humidity (60-70\%), and temperature $\left(21^{\circ} \mathrm{C}\right)$. The International guidelines for the care and use of laboratory animals were followed throughout the study.

\footnotetext{
1.Study from Núcleo de Cirurgia Experimental, Programa de Pós-Graduação em Ciências da Saúde, Universidade Federal do Rio Grande do Norte (UFRN), Natal, Brazil.

2.Postgraduate student (doctorate) from Programa de Pós-Graduação em Ciências da Saúde-UFRN.

3.From Programa de Pós-Graduação em Ciências da Saúde-UFRN.

4.Statistics undergraduate student-UFRN.

5.Medical student from Programa de Iniciação Científica-UFRN, bolsista PIBIC-CNPq.

6.Veterinary ESAM student.
} 
b) Fernando Paulino jejunal pouch: (FP) The total a)Sham: (S) Sham operation was performed by $3 \mathrm{~cm}$ midline laparotomy under ketamine hydrochloride $(100 \mathrm{mg} / \mathrm{kg})$ and xylazine $(15 \mathrm{mg} / \mathrm{kg})$ anesthesia. The stomach and the intestine were covered with saline-moistened gauze for 40 minutes, which corresponds to the time period required for the other surgical procedures.

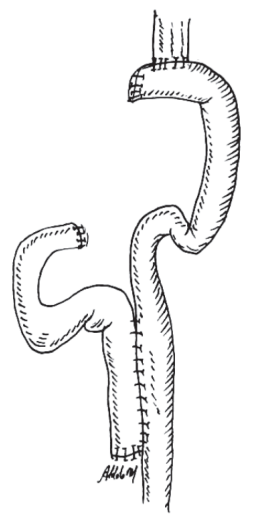

FIGURE 1 - Isoperistaltic Fernando Paulino pouch ${ }^{8}$

c) Jejunal pouch interposition graft: (JP) After total gastrectomy the jejunum was divided $5 \mathrm{~cm}$ distal to the ligament of Treitz. The digestive reconstruction method gastrectomy was done and the jejunum was divided $10 \mathrm{~cm}$ distal to the ligament of Treitz ${ }^{8}$. The distal end of jejunum was anastomosed with the transected esophagus using single stitches (6-0 polipropilene). A jejujonojejunal pouch was done, as seen in figure 1 . The anastomosis were performed by using a (9x) binocular microscope (DF VasconcelosÒ, Brazil). included interposition of a jejunal pouch reservoir between the esophagus and duodenum, preserving the duodenal passage (Figure 2).

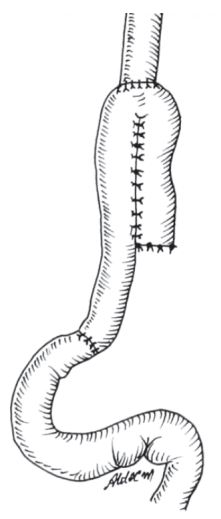

FIGURE 2 - Jejunal pouch interposition graft

After the operations the rats had an infusion of Ringer 10ml/ $\mathrm{Kg}$ intraperitoneal and free access to oral glucose $10 \%$ was permitted. Rats resumed to normal diet on third postoperative day. If some animal died before the $60^{\text {th }}$ postoperative day $\left(8^{\text {th }}\right.$ week), it was substituted in order to complete 10 rats in each group and the mortality was computed. They were weighted on the same scale each two weeks. A recovery period of eight weeks was allowed for all operated animals before the following experiments were commenced.

\section{Histological procedures}

After eight weeks the rats were killed with overdose of anesthetic and tissue was taken from the distal esophagus (1 $\mathrm{cm}$ distant to the anastomosis) for investigation with regard to esophagitis. They were fixed in $10 \%$ formalin, embedded in paraffin, cut at $4 \mu \mathrm{m}$, and stained with hematoxylin and eosin.
The following parameters were considered: 1- loss of surface epithelium; 2- neutrophil infiltration; 3 - increased height of the basal cell layer of the squamous epithelium; 4 - increased depth of the papillae. Diagnosis of esophagitis was positive when 2 or more of these parameters were present. Duodenal mucosa was examined in regard to height of cripts, Brunner's glands and celularity.

\section{Laboratory tests}

Laboratory measurements were performed before and eight weeks after the operations. Serum levels of total proteins, albumin, iron, transferring, folate, cobalamine, and calcium were determined with an autoanalyzer (Weiner Lab BT Plus 3000). Gastrinemia was measured by a double-antibody liquid phase radioimmunoassay. 


\section{Statistical analysis}

Datas were analysed by one way variance ANOVA complemented with Newman-Keuls tests. Differences were considered significant at $\mathrm{p}<0.05$ in the two-tailed tests.

\section{Results}

Forty six rats were operated. Thirty survived for eight weeks. Five $(33.3 \%)$ died soon in the postoperative period in the FP group, and $11(52.3 \%)$ of group JP died before the fourth week (Table 1). The difference in mortality was significant $(\mathrm{p}<0.05)$.
Postoperative esophagitis occurred in 6 survived rats of the group JP. Loss of surface epithelium, neutrophil infiltration and, increased depth of the papillae were found in 2 rats of this group. Increased height of the basal cell layer of the squamous epithelium and neutrophil infiltration were found in 4 rats. The FP rats had low increasing in height of the basal cell layer, and the sham rats had no signs of histological esophagitis. In group FP it was observed inflammatory reaction, atrophy of duodenal mucosa and, the JP rats showed no mucosal pathological signs.

TABLE 1 - Operative mortality

\begin{tabular}{llll}
\hline Groups & Operated rats $(\mathrm{n})$ & Mortality $\mathrm{n}(\%)$ & Survived after 8 weeks \\
\hline FP & 15 & $5(33.3 \%)$ & 10 \\
JP & 21 & $11(52.3 \%)^{*}$ & 10 \\
Sham & 10 & $0(0.0 \%)$ & 10 \\
Total & 46 & $16(34.7 \%)$ & 30 \\
\hline
\end{tabular}

* p $<0.05$ compared to FP group. Values are expressed as mean \pm SEM; FP, Fernando Paulino pouch; JP, jejunal pouch interposition graft.

The weight evolution showed a significant weight reduction on the first four weeks in group FP, and a partial weight gain until the $8^{\text {th }}$ week. In JP rats the weight reduction occured in course of the $5^{\text {th }}$ week, and they stabilized in the ${ }^{8 \text { th }}$ week (Figure 3).

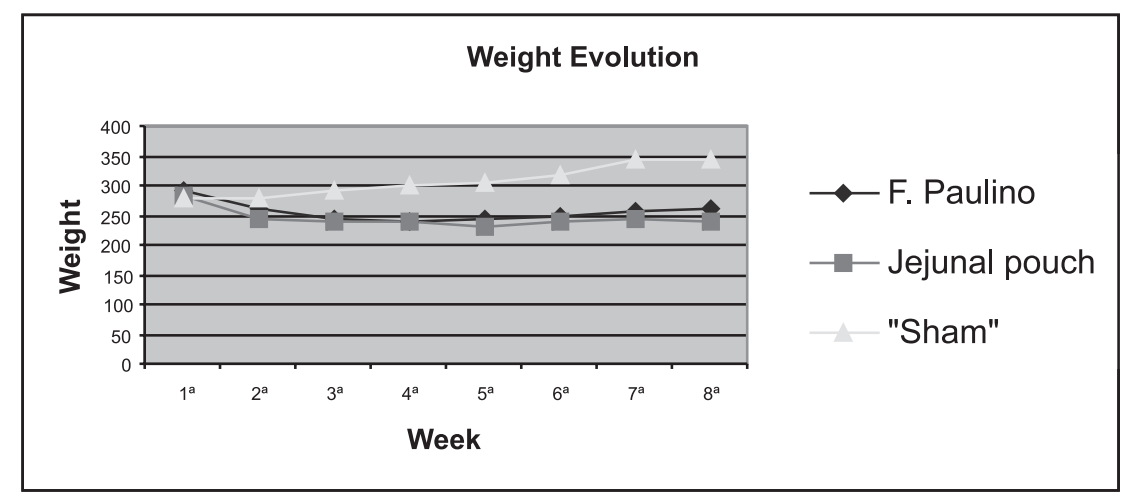

FIGURE 3 - Weight evolution of rats subjected to total gastrectomy and Fernando Paulino pouch, jejunal pouch and sham. No difference was observed between FP and JP groups $(p>0,05)$

The JP interposition graft was associated with a significant decrease in serum albumin, glucose, transferrin, folate and cobalamine concentration in the $8^{\text {th }}$ postoperative week, when compared to sham operated rats $(\mathrm{p}<0.05)$; calcium and iron was unaffected (table 2). JP rats in the preoperative period, as compared to $8^{\text {th }}$ week, displayed a significant decrease in serum albumin, glucose, transferrin, folate and cobalamine $(\mathrm{p}<0.05)$. Glucose and cobalamine serum concentrations showed significantly reduced in FP rats when compared to $\mathrm{S}$ rats in $60^{\text {th }}$ postoperative day $(\mathrm{p}<0.05)$. In FP rats, only transferrin showed significant decrease comparing the preoperative with $8^{\text {th }}$ week postoperative levels $(\mathrm{p}<0.05)$. The serum gastrin levels showed significantly reduced in FP rats compared to JP and sham rats $(\mathrm{p}<0.05)$. 
TABLE 2 - Laboratory findings at preoperative and eight weeks after operation

\begin{tabular}{llll}
\hline Laboratory parameter & Group & Preoperative & $\mathbf{8}^{\text {th }}$ week \\
\hline Albumin $(\mathrm{g} / \mathrm{dL})$ & Sham & $3.6 \pm 0.5$ & $3.8 \pm 0.3$ \\
& FP & $3.4 \pm 0.2$ & $3.1 \pm 0.2$ \\
& JP & $3.4 \pm 0.4^{* *}$ & $2.7 \pm 0.3^{*}$ \\
Glucose $(\mathrm{mg} / \mathrm{dL})$ & Sham & $102 \pm 13.1$ & $99 \pm 6.3$ \\
& FP & $96 \pm 10.3$ & $86 \pm 23.7^{*}$ \\
& JP & $100 \pm 14.3^{* *}$ & $80 \pm 12.1^{*}$ \\
Transferrin $(\mathrm{mg} / \mathrm{dl})$ & Sham & $236 \pm 20.4$ & \\
& FP & $224 \pm 22.8^{\S}$ & $229 \pm 24.1$ \\
& JP & $231 \pm 19^{* *}$ & $160 \pm 15^{* *}$ \\
& & & $163 \pm 21.3^{*}$ \\
Iron $(\mu \mathrm{g} / \mathrm{dL})$ & Sham & $288 \pm 13$ & \\
& FP & $277 \pm 12.6$ & $286 \pm 22$ \\
& JP & $268 \pm 12^{* *}$ & $223 \pm 14.1$ \\
& & & $279 \pm 20.2^{*}$ \\
Folate $(\mathrm{ng} / \mathrm{ml})$ & Sham & $8.5 \pm 3.1$ & $8.2 \pm 1.9$ \\
& FP & $8.1 \pm 2.0$ & $7.5 \pm 2.5$ \\
& JP & $8.1 \pm 2.4^{* *}$ & $7.2 \pm 0.7^{*}$ \\
Cobalamine $(\mathrm{pmol} / \mathrm{L})$ & Sham & $221 \pm 18$ & $214 \pm 20.4$ \\
& FP & $234 \pm 22^{\S}$ & $163 \pm 14^{*}$ \\
& JP & $219 \pm 23.2^{* *}$ & $161 \pm 12.7^{*}$ \\
& & & \\
Gastrin $(\mathrm{pg} / \mathrm{mL})$ & Sham & $8.4 \pm 0.5$ & $9.7 \pm 1.8$ \\
& FP & $9.1 \pm 0.8$ & $6.6 \pm 3.3$ \\
& JP & $8.9 \pm 1.6^{* *}$ & $8.5 \pm 2.0^{*}$ \\
& FPam & $128.5 \pm 7.8$ & $133.7 \pm 10.2$ \\
& JP & $122.3 \pm 9.0^{* *}$ & $17.4 \pm 3.1^{*}$ \\
& & $117.8 \pm 10.4^{* *}$ & $86.4 \pm 8.2^{*}, 8$ \\
\hline
\end{tabular}

Values are expressed as means \pm SEM; FP, Fernando Paulino pouch; JP, jejunal pouch interposition graft. $* \mathrm{p}<0.05$ compared to sham $8^{\text {th }}$ week; $\S \mathrm{p}<0.05$ compared to FP $8^{\text {th }}$ week; $* *$ p $<0.05$ compared to JP $8^{\text {th }}$ week

\section{Discussion}

It has been hypothesised that passage of food across the duodenum, resulting in the mixture of chyme with biliary and pancreatic secretions, aids in digestion, absorption, and the stimulation of the remaining intestinal tract ${ }^{4,5}$. These processes should result in better calcium and iron absorption with improved lipid and protein digestion ${ }^{7}$. In fact, in the present study calcium and iron showed high serum levels when compared the pouch with duodenal passage with the F. Paulino pouch. The formation of an appropriate replacement gastric reservoir, to simulate pre-operative gastric volume, is considered important. Construction of an enteric pouch is thought to enable the patient to consume larger, more customary, and satisfying meals ${ }^{4,6}$. A pouch should therefore improve the patients quality of life, allow them to ingest more calories, and help to prevent malabsorption and weight loss. Compared to sham, weight loss occurred in the two pouches tested in our study, and no difference was observed between them. Paulino and Roselli ${ }^{8}$ reported, in 1973, notably satisfying results in patients with a distal jejunojejunal pouch, tested in the present work. They described the use of either an isoperistaltic or antiperistaltic side-to-side attachment of the proximal afferent to the efferent jejunum, at the Roux-en-Y level, together with an end-to-end esophagojejunal anastomosis. The isoperistaltic technique was used in the present study.

The optimal reconstruction protocol after total gastrectomy is still a matter of debate. Given the decreasing morbidity and mortality rates after total gastrectomy ${ }^{911,19}$, this issue is gaining even more importance. Pouch reconstructions are developed to create a larger reservoir with a better reflux barrier; of all, the reconstruction types without restoration of the duodenal passage, are used most often. An alternative is the interposition of a jejunal loop with reestablishment of the duodenal passage. Preservation of the duodenal passage should result in better physiologic enrichment of the chyme with bile and pancreatic juice and better physiologic regulation of gastrointestinal hormones, thereby offering substantial 
advantages ${ }^{4}$. The ideal reconstruction should supply the patient with a sufficiently large reservoir to accommodate more extensive meals. It should also act as a reflux barrier to avoid reflux esophagitis and should enable optimum utilization of the administered substrates. These practical demands are theoretically best served by the formation of a pouch with preservation of the duodenal passage, as that described by Nakayama ${ }^{16}$.

Advantages of pouch reconstructions ${ }^{9,10}$, compared to the Roux-en-Y reconstruction and the advantages of restoration of the duodenal passage ${ }^{11}$ have been repeatedly described, but definitive, statistically significant proof of the superiority of this method has not yet been presented in a prospective randomized study. Total gastrectomy patients suffer from a weight loss of $15 \%$ to $20 \%{ }^{12}$, which is less if the duodenal passage is preserved $^{13}$. In the present work the levels of serum iron and calcium were preserved in the JP rats, the animals where the duodenal passage was preserved and the iron levels showed similar to the sham group. As the iron and calcium is absorbed in duodenum, possibly this physiologic characteristic possibly turned this fact possible. In present study no difference was observed in the weight loss when compared the tested reconstructions.

After total gastrectomy iron levels are low in up to $90 \%$ of patients ${ }^{14}$. Blood glucose regulation is disturbed after gastrectomy ${ }^{12,15}$. Pathologic glucose tolerance develops if the duodenal passage is eliminated. Glucose was unaffected in FP and JP rats of the present study. Alkaline esophagitis occurs after any method of postgastrectomy reconstruction that allows reflux of bile and pancreatic secretions into the distal part of the esophagus. A Roux-en-Y esophagojejunostomy eliminates esophagitis if the length of the jejunum, between the esophagealenteric and distal jejunojejunal anastomoses, is at least 40 to $45 \mathrm{~cm}$. In fact, in the present study F. Paulino procedure eliminated esophagitis, because the referred anastomosis was very distant to esophagus in our experiment.

The gastric antrum is the richest source of gastrin. It is secreted by $G$ cells and has been localized by immunohistochemical technique ${ }^{18}$. The intestinal gastrin source is highest in the proximal duodenum and there is evidence for release of gastrin from it in response to a meal ${ }^{19}$. The total gastrin concentration is considerably less in duodenum then it is in the antrum, gradually decreasing toward the distal part of the small intestine ${ }^{20}$. Our study showed that JP rats with duodenal food passage had serum gastrin higher than FP rats, and the duodenal mucosa was almost normal when compared to sham rats. In FP rats is was observed duodenal mucosal atrophy. Gastric mucosa from the parietal cell region of man and rats have been grown in tissue culture with and without the addition of pentagastrin, proving the trophical effects of gastrin ${ }^{21}$.

In conclusion, F. Paulino pouch in rats had lower mortality than JP, and esophagitis was not detected in it. JP rats had serum gastrin, iron and calcium unaffected, possibly because of preservation of duodenal passage.

\section{References}

1. Lawrence W Jr. Reconstruction after total gastrectomy: what is preferred technique? Journal of Surgical Oncology 1996;63:215-20.

2. Troidl H, Kusche J, Vestweber KH, Eypasch E, Maul U. Pouch versus esophagojejunostomy after total gastrectomy: a randomized clinical trial. World Journal of Surgery 1987;11:699-712.

3. Cuschieri, A.: Jejunal pouch reconstruction after gastrectomy for cancer: experience in 29 patients. Br. J. Surg. 1990;77:421-4.

4. Schwarz A, Buchler M, Usinger K. Importance of the duodenal passage and pouch volume after total gastrectomy and reconstruction with the Ulm pouch: prospective randomized clinical study. World J Surg 1996; 20: 60-6.

5. Fujiwara Y, Kusunoki M, Nakagawa K. Evaluation of J-pouch reconstruction after total gastrectomy: rho-double tract vs J-pouch double tract. Dig Surg 2000; 17: 475-81.

6 Kalmar K, Cseke L, Zambo K, Horvath OP. Comparison of quality of life and nutritional parameters after total gastrectomy and a new type of pouch construction with simple Roux-en-Y reconstruction: preliminary results of a prospective, randomized, controlled study. Dig Dis Sci 2001; 46: 1791-6.

7 Horvath OP, Kalmar K, Cseke L. Nutritional and life-quality consequences of aboral pouch construction after total gastrectomy: a randomized, controlled study. Eur J Surg Oncol 2001; 27: 558-63.

8 Paulino F, Roselli A. Carcinoma of the stomach. With special reference to total gastrectomy. Curr Probl Surg 1973; 1:3-72.

9. Lygidakis NJ. Total gastrectomy for gastric carcinoma: a retrospective study of different procedures and an assessment of the new technique of gastric reconstruction. Br J Surg 1981;68:649-52.

10. Troidl H, Kusche J, Vestweber KH, Eypasch E, Maul U. Pouch versus esophagojejunostomy after total gastrectomy: a randomized clinical trial. World J Surg 1987;11:699-702.

11. Del Gaudio A, Marzo C. Interposition of the first jejunal loop for reconstruction after total gastrectomy. Int Surg 1991;76:91-4.

12. Siewert JR, Schattenmann G, Ebert R. Importance of the duodenal passage following gastrectomy. In Gastric Cancer, C. Herfarth, P. Schlag, editors. Berlin, Springer-Verlag, 1979, p. 237.

13. Cuschieri A. Jejunal pouch reconstruction after gastrectomy for cancer: experience in 29 patients. Br J Surg 1990;77:421-4.

14. Adams JF. The clinical and metabolic consequences of total gastrectomy. I. Morbidity, weight and nutrition. Scand J Gastroenterol 1967;2:137-9.

15. Butters M, Bittner R, Kieninger G, Hornung A, Schmetzer M, Beger HG. Reconstruction procedures and glucose homeostasis. Nutrition 1988;4:309-12.

16. Nakayama K. Evaluation of the various operative methods for total gastrectomy. Surgery 1956;40:488-91. 
17. Hassler H, Bochud R, Nothiger F, Stafford A. Total gastrectomy: is the early postoperative morbidity and mortality influenced by the choice of surgical procedure? World J Surg 1986;10:128-31.

18.McGuigan J, Greider MH. Correlative immunochemical and light microscopic studies of the gastrin cell of the antral mucosa. Gastroenterology 1971;60:223-26.
19. Korman MG, Soveny C, Hansky J. Extragastric gastrin. Gut 1972; 13:346-9.

20.Berson SA, Yalow RS. Nature of immunoreactive gastrin extracted from tissues of gastrointestinal tract. Gastroenterology 1971;60:215-19.

21. Lichtenberger L, Miller LR. Effect of pentagastrin on adult rat duodenal cells in culture. Gastroenterology 1973;65:242-8.

Aires-Neto T, Cavalcante JF, Brandão-Neto J, Almeida MG, Rezende AA, Egito EST, Azevedo IM, Pinheiro LAM, Medeiros VB, Medeiros AC. Gastrectomy total com substituição do estômago por bolsa jejunal com e sem passagem do alimento pelo duodeno. Estudo em ratos. Acta Cir Bras [serial on line] Available from: URL: htt://www.scielo.br/acb.

RESUMO - Objetivo: Estudo comparativo foi realizado entre a bolsa jejunal de Fernando Paulino (FP) e uma bolsa jejunal (JP) interposta entre o esôfago e duodeno, para substituir o estômago após gastrectomia . Foi investigado o efeito dos dois procedimentos na histologia do esôfago, estado nutricional e gastrinemia sérica em ratos. Métodos: Quarenta e seis ratos Wistar pesando $282 \pm 17 \mathrm{~g}$ foram aleatoriamente submetidos a sham operation $(\mathrm{S}), \mathrm{FP}$ e JP após gastectomia total. Decorridas 8 semanas, foi colhido sangue por punção cardíaca para dosagem de proteínas totais, albumina, ferro, transferrina, folato, cobalamina, calcio, e gastrina. Os animais receberam dose letal de anestésico e tecido do esôfago terminal foi retirado para histologia. Foi observada a mortalidade operatória dos animais. Resultados: Quarenta e seis ratos foram operados e 30 sobreviveram por 8 semanas. Cinco (33,3\%) morreram após FP e $11(52,3 \%)$ após JP (p<0.05). Esophagitis pós-operatória ocorreu em 6 ratos JP. Na $8^{\mathrm{a}}$ semana o peso corporal foi maior nosratos submetidos a FP do que JP ( $>>0.05)$. Os ratos submetidos a JP tiveram uma diminuição significativa na albumina, glucose, transferrina, ferro, folato e cálcio, comparado com o sham ( $\mathrm{p}<0.05)$. Os níveis de gastrina sérica, ferro e calcio mostraram-se significantemente maiores nos ratos submetidos a JP do que nos FP ( $\mathrm{p}<0.05)$. Nos ratos FP a transferrina e a cobalamina estiveram significantemente diminuídas comparando-se os níveis do pré-operatório com a 8 a semana (p<0.05). Conclusão: A bolsa jejunal de F. Paulino, em ratos, resultou em mortalidade operatória e incidência de esofagite de refluxo menor do que a interposição de JP. AJP não afetou a dosagem sérica de gastrina, ferro e cálcio, provavelmente devido à preservação da passagem dos alimentos pelo duodeno.

DESCRITORES: Gastrectomy total. Bolsa jejunal. Nutrição. Gastrina. Refluxo.

Correspondence:

Aldo da Cunha Medeiros

Av. Miguel Alcides Araújo 1889

59078-270 Natal, RN, Brasil

E-mail: aldo@ufrnet.br 